일 반논문-09-14-4-12
$\mathrm{AT}-\mathrm{DMB}$ 시스템을 위한 계층변조 방식의 성능 분석
이 상 진 ${ }^{a)}$, 이 상 운 ${ }^{\ddagger}$, 양 규 태 ${ }^{c)}$, 임 종 수 ${ }^{\mathrm{c}}$

\title{
Study on the Performance of Hierarchical Modulation for AT-DMB System
}

\author{
Sang-Jin Lee ${ }^{\text {a) }}$, Sangwoon Lee ${ }^{\text {b) }}$, Kyu-tae Yang ${ }^{\text {c) }}$, and Jong-Soo Lim ${ }^{\text {c) }}$ \\ 요 약
}

본 논문에서는 기존의 T-DMB(Terrestrial-DMB) 방식과 호환성을 유지하는 동시에 이동환경에서 고전송 효율, 고품질 서비스를 제공할 수 있는 새로운 휴대 이동 방송 방식인 AT-DMB(Advanced T-DMB) 시스템을 소개한다. AT-DMB 시스템에 새로 도입된 계층 변조방식은 기존의 데이터 스트림에 부가적인 데이터 스트림을 삽입하여 전송할 수 있고, 이에 따라 AT-DMB는 기존의 T-DMB보다 더 많은 유효데이터를 전송할 수 있어 고품질 비디오 서비스를 제공할 수 있으며, 동시에 많은 방송 서비스 채널을 제공할 수 있게 된다. 본 논문에서는 AT-DMB 시스템에서 새롭게 도입된 계층변조 방식과 기존의 T-DMB 시스템과의 성능을 비 교하고 다양한 환경에서 계층변조에 의한 성능을 분석하였다.

\section{Abstract}

This paper introduces an Advanced Terrestrial DMB (AT-DMB) system which provides higher efficiency of transmission and better quality of service than conventional T-DMB system. In AT-DMB, a hierarchical modulation method is applied to transmit more data while maintaining backward compatibility to conventional T-DMB receivers. This method can provide not only high quality video service but also lots of broadcasting channels. In this paper, the performance of the hierarchical modulation in AT-DMB system is analyzed with computer simulation in several environments compared with the performance of T-DMB system.

Keyword : T-DMB, Advanced T-DMB, hierarchical modulation, mobile broadcasting, OFDM, Turbo code

\section{I. 서 론}

2005년 12월에 세계 최초의 상용 휴대이동 방송 서비스로 시작된 T-DMB는 현재 비디오, 오디오 및 데이터 서비스를

a) 연세대학교 전기·전자공학과

Dept. of Electrical \& Electronic Eng., Yonsei University

b) 남서울대학교 멀티미디어학과

Dept. of Multimedia, Namseoul University

c) 한국전자통신연구원 이동방송기술연구팀

Terrestrial Transmission Technology Research Team, Electronics and

Telecommunications Research Institute

\$ 교신저자 : 이상운(Quattro@nsu.ac.kr)

· 접수일(2009년5월10일),수정일(2009년7월29일),게재확정일(2009년7월29일)
통합하여 제공하고 있다. T-DMB는 유럽의 $\mathrm{DAB}$ 기술인 Eureka-147 시스템을 확장하여 국내 기술로 개발되었으며, 가정, 차량, 야외 등에서 고음질, 다채널의 오디오 서비스뿐 만 아니라 $\mathrm{CIF}$ 급의 비디오 서비스, 고수익의 비즈니스 모델 을 지원하기 위한 다양한 데이터서비스를 지원할 수 있다. 한편, 유럽에서는 DVB-H (Digital Video BroadcastingHandheld) 방식을 이용하여, 2006년 5월 이탈리아에서 처 음으로 상용서비스를 실시하였다. 또한, 미국에서는 퀄컴이 주도한, FLO (Forward Ling Only) 방식을 개발하여 2007년 3 월부터 미국의 일부 주에서 상용 서비스를 시작하였다. 이 러한 상용서비스가 시작된 휴대이동 방송기술 중에서 T- 
$\mathrm{DMB}$ 는 송출장비 설치비용이 상대적으로 저렴하고, 방송 커 버리지가 넓다는 장점이 있으나 다른 방식들에 비해 주파수 대비 가용 채널수가 작은 단점을 가지고 있다. 이러한 단점을 극복하고 세계 최초의 휴대 이동 방송 시스템으로서의 경쟁 력을 유지하기 위해서 T-DMB의 유효 데이터 전송률(effective data rate)을 증대시키고자 하는 노력이 진행되고 있다.

이러한 요구사항에 의해 개발되고 있는 Advanced T$\mathrm{DMB}$ 는 새롭게 도입되는 계층변조에 의한 증대되는 유효 데 이터 전송률을 활용하여, 동일 주파수 대역에서 기존 T-DMB 방송에 비해 최대 2 배까지의 가용 서비스 수를 증가시킬 수 있으며, 또한 $\mathrm{SD}$ 급의 해상도로 제작된 비디오 콘텐츠를 $\mathrm{AT}-\mathrm{DMB}$ 를 통하여 VGA 크기의 화면으로 제공이 가능하다. 따라서, AT-DMB 기술은 휴대이동 방송과 지상파 DTV를 동시에 제공할 수 있는 경제적인 대체 수단이 될 수 있어, 휴 대 이동 방송의 확산과 더불어 해외 디지털 방송 시장 개척에 매우 중요한 역할을 할 것으로 기대하고 있다. 그러나 AT$\mathrm{DMB}$ 상용 서비스를 위해서는 기존 T-DMB와의 역호환성이 반드시 보장되어야 하며, 기존 T-DMB 서비스 커버리지에 대 한 영향을 최소화하여야 하는 전제조건을 갖고 있다.

본 논문에서는 AT-DMB 시스템과 새롭게 도입된 계층 변조 방식에 대해 소개하고, 이동환경 에서의 성능 향상을 위한 계층변조 B 모드와 고정환경에서의 성능 향상을 위한 계층변조 $\mathrm{Q}$ 모드의 신호 생성 방식 및 성능을 분석하였다.

\section{AT-DMB를 위한 계층변조}

\section{AT-DMB 시스템}

AT-DMB시스템은 기본계층과 향상계층의 두 계층으로 구성되어 있다. 기본계층(HP: High Priority)은 기존의 지상 파 $\mathrm{DMB}$ 서비스를 지원하는 계층으로서, 기존 지상파 $\mathrm{DMB}$ 수신기와 새롭게 개발될 $\mathrm{AT}-\mathrm{DMB}$ 수신기로 수신될 수 있다. 향상 계층(LP: Low Priority)은 기존 지상파 DMB 의 데이터 전송용량을 증가시키기 위해서 기본계층에 계층 변조를 적용하여 추가한 계층으로서 AT-DMB 수신기로만 수신이 가능하다. AT-DMB 시스템은 그림1에 나타낸 바와
같이 송신단과 수신단으로 구성되며, 송신단은 기본계층 프레임 발생부, 향상계층 프레임 발생부, 계층 변조, OFDM 변조기 및 지상파 링크등으로 구성된다.

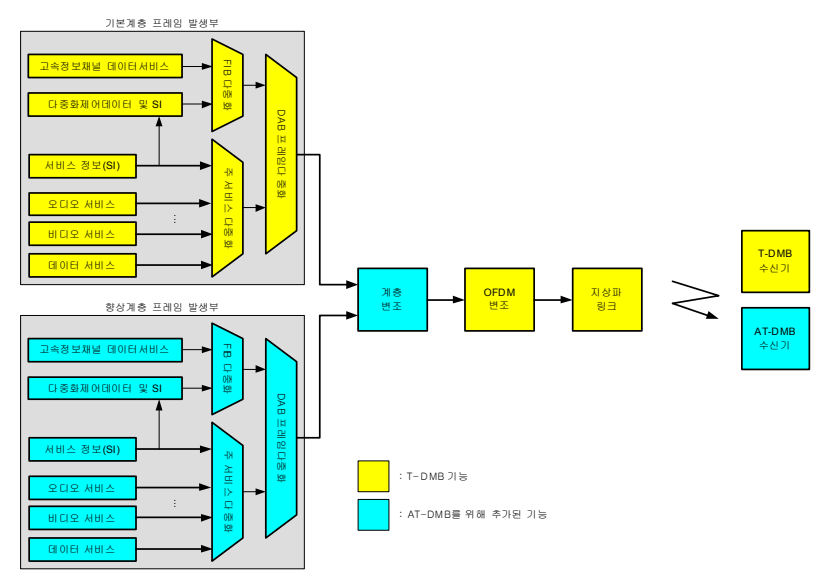

그림 1. AT-DMB 시스템 구성도

Fig. 1. Block diagramof AT-DMB system

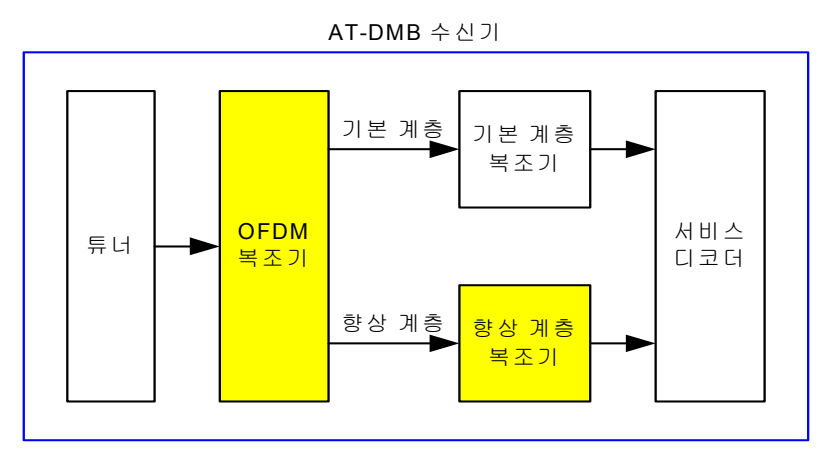

그림 2. AT-DMB 수신기 개요도

Fig. 2. Concept of AT-DMB receiver

향상계층 프레임 발생부는 향상계층의 오디오, 비디오 및 데이터 서비스 신호의 입력 장치, 향상계층의 $\mathrm{DAB}$ 프레 임다중화기로 구성된다. AT-DMB 수신기의 개요도는 그 림 2와 같다. AT-DMB 수신기의 OFDM 복조기에서, T$\mathrm{DMB}$ 에 해당하는 기본 계층 데이터는 기본 계층 복조기로 전송되고, 향상계층 데이터는 향상 계층 복조기로 전송된 다. 기본 계층과 향상 계층 복조기는 데이터를 복조한 다음 해당 서비스 디코더로 전송한다.

향상계층은 수신환경을 고려하여 계층변조 $\mathrm{B}$ 모드와 계 
층변조 $\mathrm{Q}$ 모드의 2 종류의 계층변조 모드로 나뉘어있다. 계층 변조 B모드는 BPSK 심볼 매핑을 이용하고, 계층변조 $\mathrm{Q}$ 모드는 $\mathrm{QPSK}$ 심볼 매핑을 이용한다. 계층변조 $\mathrm{B}$ 모드는 계층변조 $\mathrm{Q}$ 모드와 비교하여 채널 유효전송용량은 줄어드 나, 이동 채널에서의 수신 성능이 더 우수한 장점이 있다.

\section{2. 심볼 매핑}

\section{1 계층변조 B 모드}

그림 3은 기존 T-DMB의 변조방식인 $\pi / 4-\mathrm{DQPSK}$ 의 신 호 성상도이다. $\pi / 4-\mathrm{DQPSK}$ 는 홀수번째 심볼과 짝수번째 심볼의 성상에 변화를 줌으로써 $\pm 45^{\circ}, \pm 135^{\circ}$ 의 위상 변화

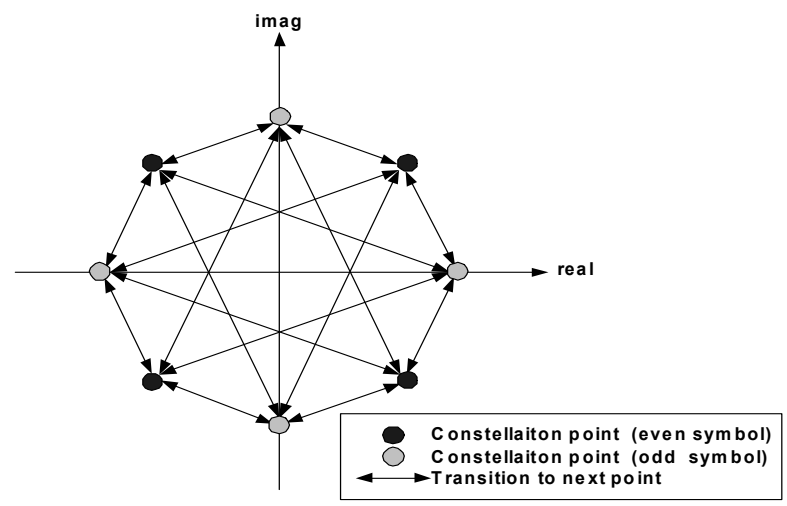

그림 3. 차등변조된 $\pi / 4-D Q P S K$ 신호 성상도

Fig. 3. Constellation of $\pi / 4-D Q P S K$ symbol

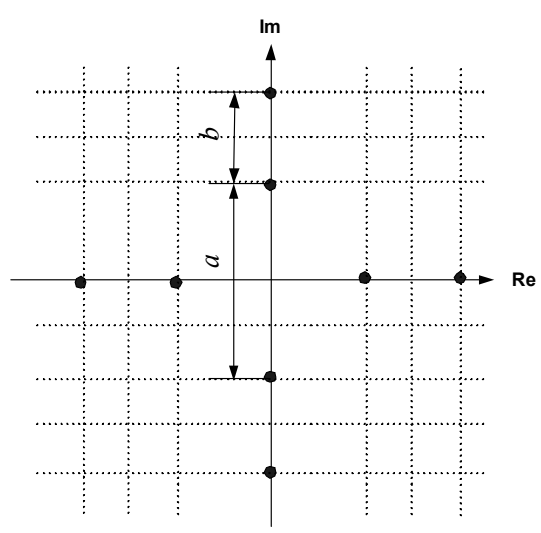

(a) 홀수 번째 심볼의 성상도
를 갖는 변조방식이다.

$\mathrm{AT}-\mathrm{DMB}$ 에 새롭게 도입된 계층변조 방식 중 $\mathrm{B}$ 모드는 고속이동환경을 고려하여, 기존의 T-DMB 방식에 비해 약 1.5 배의 전송용량을 증대시킬수 있는 방식이다. 계층변조 심볼 매핑은 기본계층 심볼 매핑과 향상계층 심볼 매핑으 로 구분된다. 향상계층 비트열은 BPSK 심볼로 매핑된다.

계층변조 B 모드에서 계층변조는 그림3에 나타낸 기본 계층의 $\pi / 4-\mathrm{DQPSK}$ 심볼과 그림 4에 나타낸 향상계층의 $\mathrm{BPSK}$ 심볼을 결합하여 수행하며 그림 5와 같이 계층변조

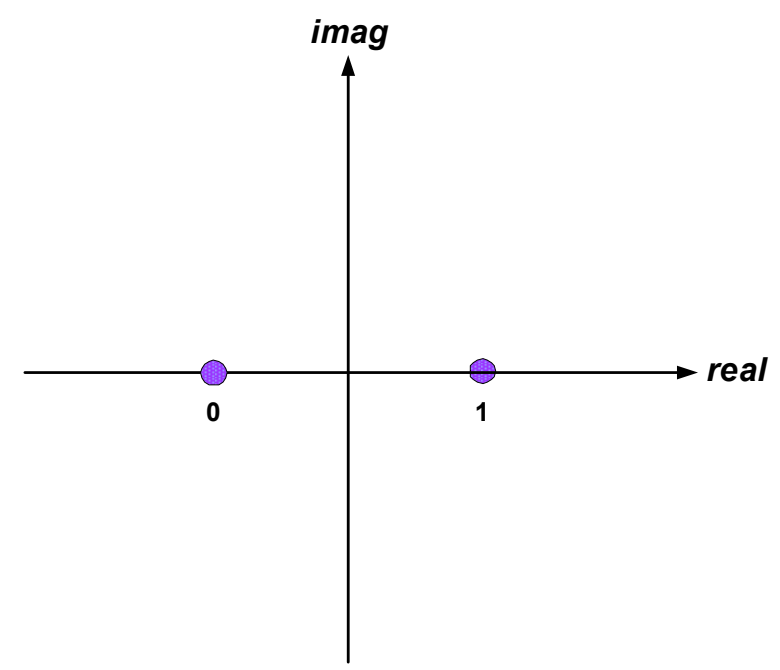

그림 4. 계층변조 B 모드의 BPSK 심볼 성상도

Fig. 4. Constellation of BPSK symbol for hierarchical modulation (B Mode)

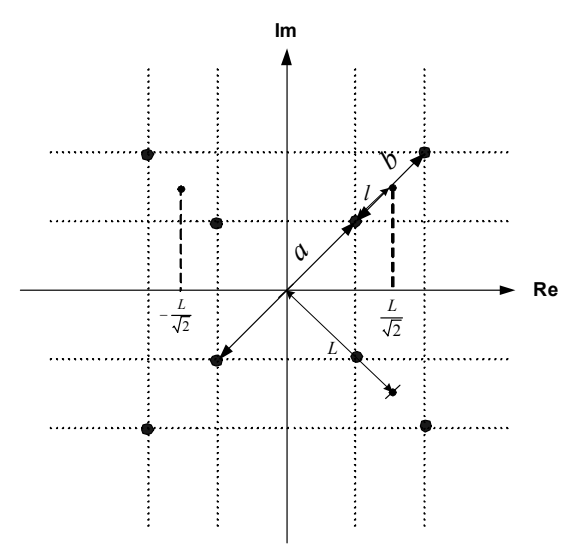

(b) 짝수 번째 심볼의 성상도

그림 5. 계층변조 B 모드에서 계층변조 된 신호의 성상도

Fig. 5. Constellation of hierarchical modulation symbol in $B$ mode 
된 새로운 성상을 나타낸다. 계층변조 B 모드에서 계층변 조의 성상비 $a$ 는 식 (1)과 같이 정의된다.

계층변조는 차동변조된 기본계층의 $\pi / 4-\mathrm{DQPSK}$ 심볼과 향상계층의 BPSK 출력심볼을 결합하여 수행한다. 계층변 조는 고속정보채널과 주 서비스채널에 대해서 적용되며, 동기채널에 대해서는 적용되지 않는다.

$$
\alpha=\frac{a}{b}
$$

$a$ 는 $(1.5,2.0,2.5,3.0)$ 의 4종류 값을 가진다. 그리고 $a$ 를 변경하여 기본계층과 향상계층의 오류율을 조절함으로써 기본계층과 향상계층의 방송권역을 조정할 수 있다. 계층 변조는 식 (2)와 같이 향상계층의 BPSK 심볼의 크기를 조 정한 후에 기본계층 심볼과 더하는 과정으로 이루어진다.

$$
\begin{aligned}
& S_{l, k}^{\text {Hier }}=z_{l, k}+\frac{1}{1+\alpha} q_{l, k}^{L P} \cdot e^{j\left[\operatorname{ang}\left(z_{l, k}\right)\right]} \text { for } l=2,3, \ldots, 76 \\
& \text { and }-\frac{k}{2} \leq k \leq \frac{k}{2}
\end{aligned}
$$

$$
\operatorname{ang}\left[z_{l, k}\right]=\tan ^{-1} \frac{\operatorname{Im}\left\{z_{l, k}\right\}}{\operatorname{Re}\left\{z_{l, k}\right\}}
$$

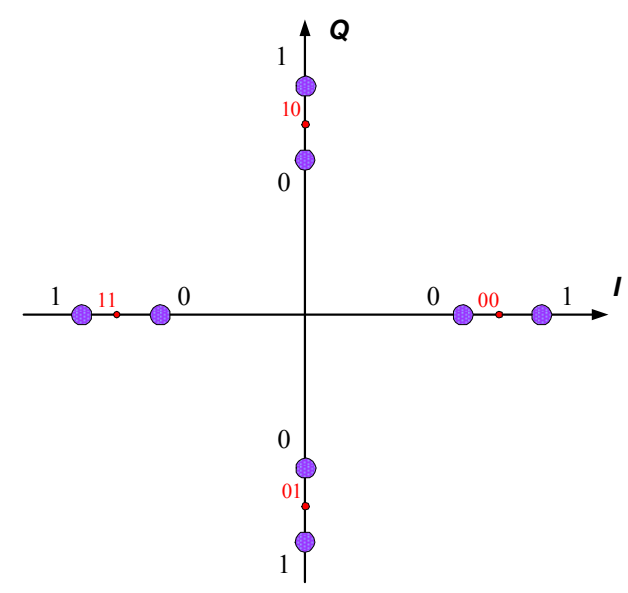

(a) 홀수번째 심볼
위의 식에서 $S_{l, k}^{H i e r}$ 는 계층변조된 심볼이며, $l, k$ 는 각각 $\mathrm{OFDM}$ 심볼의 시간 지수와 부반송파 지수이고, $z_{l, k}$ 는 $\pi$ /4-DQPSK 변조된 기본계층 심볼, $q_{l, k}^{L P}$ 는 BPSK로 변조된 향 상계층 심볼을 나타낸다. $z_{l, k}$ 와 $q_{l, k}^{L P}$ 의 전력은 모두 1 이다.

그림 6에 계층변조 $\mathrm{B}$ 모드 계층 변조기의 구조를 나타내 었다.

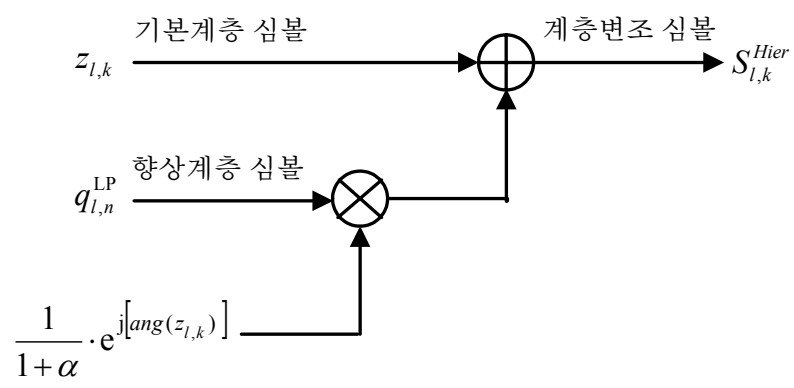

그림 6. 계층변조 B 모드 계층 변조기 구성도

Fig. 6. Block diagram of hierarchical modulator for $B$ mode

그림 7은 계층변조된 $\mathrm{AT}-\mathrm{DMB}$ 신호의 심볼 의 비트 매 핑 결과이다.

2.2 계층변조 $Q$ 모드

계층변조 $\mathrm{Q}$ 모드는 저속이동환경 혹은 고정 수신 환경을

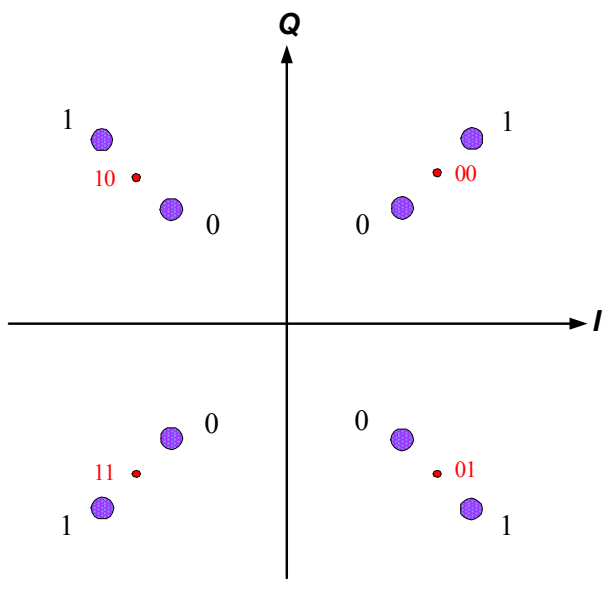

(b) 짝수번째 심볼

그림 7. 계층변조 $\mathrm{B}$ 모드에서 계층변조된 $\mathrm{AT}-\mathrm{DMB}$ 신호의 비트 매핑

Fig. 7. Bit mapping of AT-DMB symbol in hierarchical modulation (B mode) 
위한 모드로, 기존 T-DMB 방식보다 최대 2배의 전송효율 을 증가 시킬 수 있는 방식이다. Q 모드에서의 계층변조는 그림 3과 그림 8의 심볼을 결합한 형태 이며, $\mathrm{Q}$ 모드로 계 층 변조된 신호의 성상은 그림 9 와 같다. $\mathrm{Q}$ 모드에서 계층변 조의 성상비 $a$ 는 식 (1)과 같이 동일하게 정의된다.

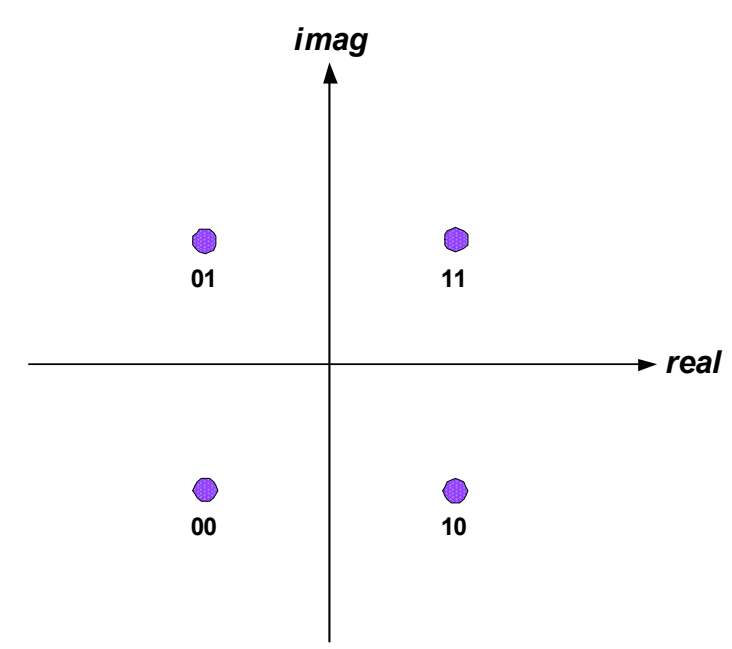

그림 8. 계층변조 $\mathrm{Q}$ 모드의 QPSK 심볼 성상도

Fig. 8. Constellation of QPSK symbol for hierarchical modulation (Q Mode)

$\mathrm{Q}$ 모드 에서의 계층변조는 식 (4)와 같이 향상계층의 QPSK 심볼을 회전시키고 크기를 조정한 후에 기본계층 심

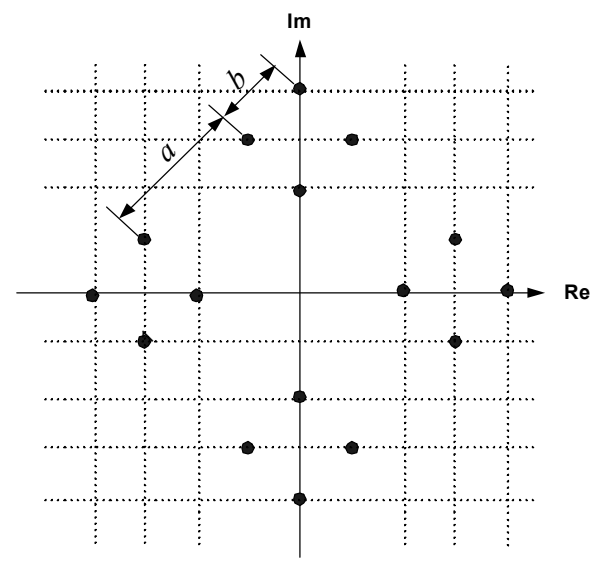

(a) 홀수번째 심볼의 성상도
볼과 더하는 과정으로 이루어진다.

$$
\begin{gathered}
S_{l, k}^{\text {Hier }}=z_{l, k}+\frac{1}{1+\alpha} q_{l, k}^{L P} \cdot e^{j\left[\operatorname{ang}\left(z_{l, k}\right)-\frac{\pi}{4}\right]} \text { for } \\
l=2,3, \ldots, 76 \text { and }-\frac{k}{2} \leq k \leq \frac{k}{2} \\
\operatorname{ang}\left[z_{l, k}\right]=\tan ^{-1} \frac{\operatorname{Im}\left\{z_{l, k}\right\}}{\operatorname{Re}\left\{z_{l, k}\right\}}
\end{gathered}
$$

위의 식에서 $z_{l, k}$ 는 $\pi / 4-\mathrm{DQPSK}$ 변조된 기본계층 심볼, $q_{l, k}^{L P}$ 는 QPSK로 변조된 향상계층 심볼을 나타낸다. $z_{l, k}$ 와 $q_{l, k}^{L P}$ 의 전력은 모두 1 이다.

그림 10 은 $\mathrm{Q}$ 모드 계층 변조기의 구조를 보여준다.

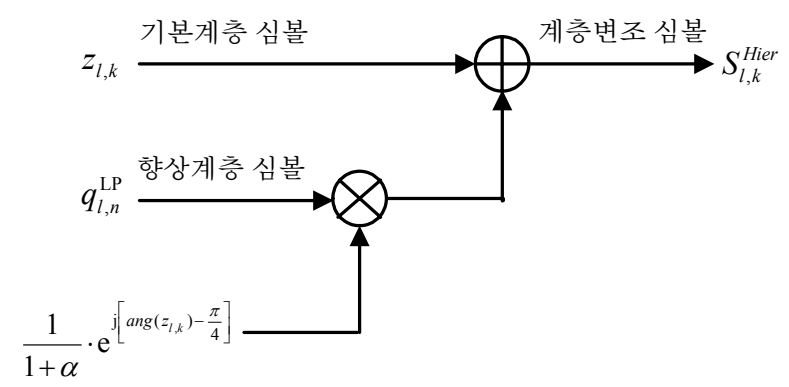

그림 10. 계층변조 $Q$ 모드 계층 변조기 구성도

Fig. 10. Block diagram of hierarchical modulator for $Q$ mode

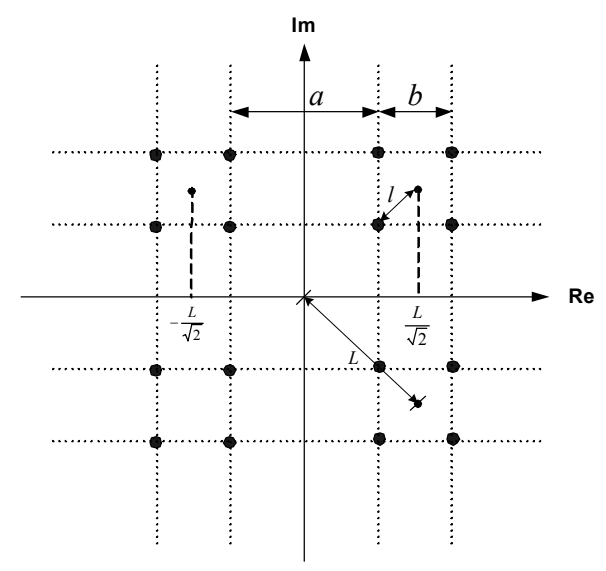

(b) 짝수번째 심볼의 성상도

그림 9. 계층변조 $Q$ 모드에서 계층변조된 신호의 성상도

Fig. 9. Constellation of hierarchical modulation symbol in $Q$ mode 


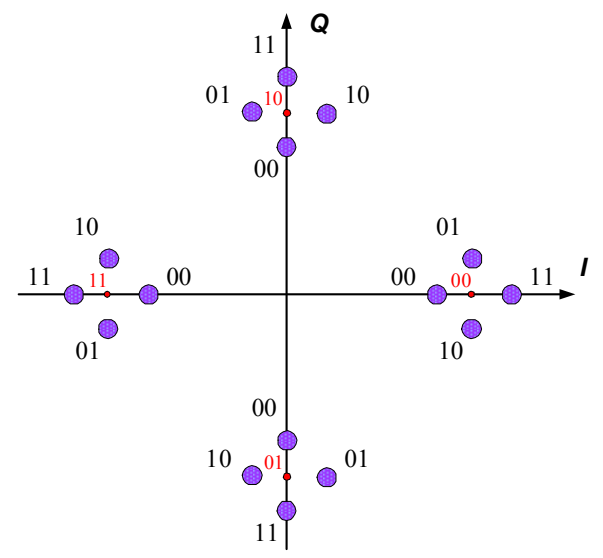

(a) 홀수번째 심볼

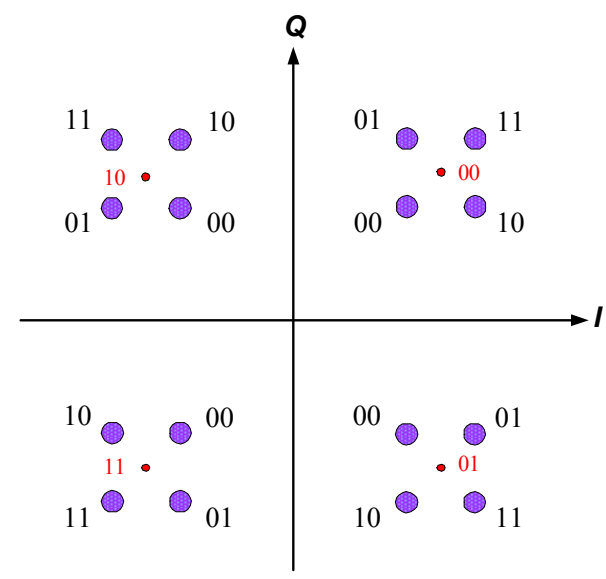

(b) 짝수번째 심볼

그림 11. 계층변조 $Q$ 모드에서 계층변조된 AT-DMB 신호의 비트매핑

Fig. 11. Bit mapping of AT-DMB symbol in hierarchical modulation ( $Q$ mode)

$\mathrm{Q}$ 모드를 통하여 생성된 AT-DMB 신호의 성상도와 이 에 따른 비트매핑은 그림 11 과 같다.

\section{III. 모의실험 결과 및 분석}

새롭게 도입된 계층변조 방식을 이용하여, 다양한 채널 환경에서 모의 전산실험을 하였다. 실험에 사용한 오류정 정부호는 $\pi / 4-\mathrm{DQPSK}$ 변조에서 길쌈부호, $\mathrm{BPSK}$ 및 $\mathrm{QPSK}$ 변조에서 터보 부호를 사용하였고, 수신기의 이동속도는 $120 \mathrm{~km} / \mathrm{h}$ 를 가정하였다. 부호화율은 두 부호 모두 기존 지 상파 $\mathrm{DMB}$ 의 MSC (main service channel) 에서 사용하는 대표적인 부호율인 $1 / 2$ 를 사용하였다.

지상파 $\mathrm{DMB}$ 의 비디오 서비스에서 수신비트오류성능은 $10^{-8}$ 이하의 비트오류율을 요구하므로, 전체 시스템에서 $10^{-8}$ 의 비트오류율을 분석하기 위하여 모의 전산실험에서
비터비 복호기 출력 비트 오율이 $10^{-4}$ 일 때 $\mathrm{C} / \mathrm{N}$ 값(요구 $\mathrm{C} / \mathrm{N})$ 을 구하였다. 이때, 유효데이터 전송률은 기본계층의 유효데이터인 $1152 \mathrm{kbps}$ 를 기준으로 정하였으며 이에 따라 향상 계층의 유효데이터는 BPSK 일때 576kbps, QPSK 일 때 $1152 \mathrm{kbps}$ 가 되도록 하였다.

표 1 은 모의전산 실험을 통하여 구한 기본계층의 요구 $\mathrm{C} / \mathrm{N}$ 값이다. 고정환경에서 채널모델이 Gaussian, Rician, Rayleigh 일때 각각 $5 \mathrm{~dB}, 5.4 \mathrm{~dB}, 8.2 \mathrm{~dB}$, 이동환경인 TU-6 모델 일때 $9.6 \mathrm{~dB}$ 의 $\mathrm{C} / \mathrm{N}$ 값을 얻을 수 있었다.

표 2는 BPSK를 향상 계층(LP: Low Priority)에 사용하는 $\mathrm{AT}-\mathrm{DMB}$ 시스템에서, 모의 전산 실험을 통하여 얻은 다양 한 환경에 따른 기본계층과 향상계층의 $\mathrm{C} / \mathrm{N}$ 값을 나타낸다. 결과를 보면 계층변조지수 $a$ 가 커짐에 따라 기본계층(HP: High Priority) 심볼의 요구 $\mathrm{C} / \mathrm{N}$ 은 감소하고 향상 계층(LP: Low Priority) 심볼의 요구 $\mathrm{C} / \mathrm{N}$ 은 증가함을 볼 수 있다. 향 상 계층의 $\mathrm{C} / \mathrm{N}$ 은 최대 유효데이터인 $576 \mathrm{kbps}$ 를 유지하기

표 1. 기본계층의 요구 $\mathrm{C} / \mathrm{N}$

Table 1. Required $\mathrm{C} / \mathrm{N}$ for Base layer

\begin{tabular}{|c|c|c|c|c|c|c|}
\hline \multirow{2}{*}{ Modulation } & \multirow{2}{*}{ 부호화율 } & \multicolumn{3}{|c|}{ 고정 } & 이동 & \multirow{2}{*}{$\begin{array}{c}\text { 유효데이터 } \\
\text { (kbps) }\end{array}$} \\
\cline { 3 - 6 } & & Gaussian & Rician & Rayleigh & TU-6 & 1152 \\
\hline$\pi / 4$-DQPSK & $1 / 2$ & 5 & 5.4 & 8.2 & 9.6 & 115 \\
\hline
\end{tabular}

$\left(\mathrm{dB}, \mathrm{BER}=10^{-4}\right.$ 비터비 복호 후) 
표 2. $B$ 모드의 요구 $\mathrm{C} / \mathrm{N}$

Table 2. Required $\mathrm{C} / \mathrm{N}$ for $\mathrm{B}$ mode

\begin{tabular}{|c|c|c|c|c|c|c|c|}
\hline \multirow{2}{*}{ Modulation I } & \multirow{2}{*}{ 계층변조지수(a) } & \multirow{2}{*}{ 부호화율 } & \multicolumn{3}{|c|}{ 고정 } & \multirow{2}{*}{$\begin{array}{c}\text { 이동 } \\
\text { TU-6 }\end{array}$} & \multirow[t]{2}{*}{ 유효데이터 (kbps) } \\
\hline & & & Gaussian & Rician & Rayleigh & & \\
\hline$\pi / 4 \mathrm{DQPSK}(\mathrm{HP})$ & \multirow{2}{*}{1.5} & $1 / 2$ & 7.9 & 8 & 10.6 & 12.7 & 1152 \\
\hline BPSK(LP) & & $1 / 2$ & 5.9 & 6.2 & 8.2 & 10.2 & 576 \\
\hline$\pi / 4 \mathrm{DQPSK}(\mathrm{HP})$ & \multirow{2}{*}{2} & $1 / 2$ & 7 & 7.4 & 9.8 & 11.7 & 1152 \\
\hline BPSK(LP) & & $1 / 2$ & 6.3 & 6.3 & 9.4 & 12.2 & 576 \\
\hline$\pi / 4 \mathrm{DQPSK}(\mathrm{HP})$ & \multirow{2}{*}{2.5} & $1 / 2$ & 6.1 & 6.8 & 9.5 & 11.3 & 1152 \\
\hline BPSK(LP) & & $1 / 2$ & 8.2 & 8.3 & 10.2 & 14 & 576 \\
\hline$\pi / 4 \mathrm{DQPSK}(\mathrm{HP})$ & \multirow{2}{*}{3} & $1 / 2$ & 6 & 6.6 & 9.2 & 10.7 & 1152 \\
\hline BPSK(LP) & & $1 / 2$ & 9.5 & 9.5 & 10.3 & 14.2 & 576 \\
\hline
\end{tabular}

$\left(\mathrm{dB}, \mathrm{BER}=10^{-4}\right.$ 비터비 복호 후)

표 3. $Q$ 모드의 요구 $C / N$

Table 3. Required $\mathrm{C} / \mathrm{N}$ for $\mathrm{Q}$ mode

\begin{tabular}{|c|c|c|c|c|c|c|}
\hline \multirow[t]{2}{*}{ Modulation II } & \multirow[t]{2}{*}{ 계층변조지수(a) } & \multirow[t]{2}{*}{ 부호화율 } & \multicolumn{3}{|c|}{ 고정 } & \multirow[t]{2}{*}{$\begin{array}{c}\text { 유효데이터 } \\
\text { (kbps) }\end{array}$} \\
\hline & & & Gaussian & Rician & Rayleigh & \\
\hline$\pi / 4 \mathrm{DQPSK}(\mathrm{HP})$ & \multirow{2}{*}{1.5} & $1 / 2$ & 10 & 10.7 & 19 & 1152 \\
\hline QPSK(LP) & & $1 / 2$ & 10.2 & 10.3 & 12.3 & 1152 \\
\hline$\pi / 4 \mathrm{DQPSK}(\mathrm{HP})$ & \multirow{2}{*}{2} & $1 / 2$ & 8.3 & 8.5 & 13 & 1152 \\
\hline QPSK(LP) & & $1 / 2$ & 10.3 & 11.4 & 14.1 & 1152 \\
\hline$\pi / 4 \mathrm{DQPSK}(\mathrm{HP})$ & \multirow{2}{*}{2.5} & $1 / 2$ & 7.2 & 7.6 & 11.5 & 1152 \\
\hline QPSK(LP) & & $1 / 2$ & 12.2 & 12.2 & 14.3 & 1152 \\
\hline$\pi / 4 \mathrm{DQPSK}(\mathrm{HP})$ & \multirow{2}{*}{3} & $1 / 2$ & 6.7 & 7 & 10.5 & 1152 \\
\hline QPSK(LP) & & $1 / 2$ & 12.3 & 13.3 & 15.6 & 1152 \\
\hline
\end{tabular}

$\left(\mathrm{dB}, \mathrm{BER}=10^{-4}\right.$ 비터비 복호 후)

위해서 Gaussian 환경에서 $a=1$ 일 때 $5.9 \mathrm{~dB}, a=2$ 일 때 $6.3 \mathrm{~dB}, a=2.5$ 일 때 $8.2 \mathrm{~dB}, a=3$ 일 때 $9.5 \mathrm{~dB}$ 의 $\mathrm{C} / \mathrm{N}$ 이 필요 함을 알 수 있다. Rician 환경에서는 Gaussian과 비슷한 $6.2 \mathrm{~dB}, 6.3 \mathrm{~dB}, 8.2 \mathrm{~dB}, 9.5 \mathrm{~dB}$ 의 $\mathrm{C} / \mathrm{N}$ 을 나타내고 있다. Rayleigh 환경에서는 $8.2 \mathrm{~dB}, 9.4 \mathrm{~dB}, 10.2 \mathrm{~dB}, 10.3 \mathrm{~dB}$ 의 결과를 보였다. TU-6 채널 환경에서는 $10.2 \mathrm{~dB}, 12.2 \mathrm{~dB}$, $14 \mathrm{~dB}, 14.2 \mathrm{~dB}$ 로 고정환경에서보다 약 $2 \sim 4 \mathrm{~dB}$ 정도 더 큰 $\mathrm{C} / \mathrm{N}$ 을 요구하고 있다. 특히, TU-6 채널 환경에서 기존의 $\mathrm{T}-\mathrm{DMB}$ 전송방식에 필요한 $\mathrm{C} / \mathrm{N}$ 값 $(9.6 \mathrm{~dB})$ 과 유사한 $\mathrm{AT}-\mathrm{DMB}$ 시스템의 기본계층 $\mathrm{C} / \mathrm{N}$ 값은 $10.4 \mathrm{~dB}(\mathrm{a}=3$ 일때 $)$ 임을 알 수 있으며, 이때 향상 계층에 필요한 $\mathrm{C} / \mathrm{N}$ 값은 14.2 $\mathrm{dB}$ 임을 알 수 있다. 이는 기존 T-DMB와 유사한 커버리지 를 AT-DMB의 기본계층이 갖도록 하기 위해서는 향상계 층에 약 $4 \mathrm{~dB}$ 의 더 많은 전력이 요구됨을 알 수 있다. 반면, $a=1$ 일 때는 AT-DMB 시스템의 향상계층이 기존의 T$\mathrm{DMB}$ 와 유사한 커버리지를 갖는 반면, 기본 계층은 커버리 지가 줄어듬을 알 수 있다. 그러나, 두 경우 모두 기존의 $\mathrm{T}-\mathrm{DMB}$ 보다 전송량이 $576 \mathrm{kbps}$ 더 증가하여 전송된다는 것을 알 수 있다.

표 3은 QPSK를 향상 계층에 사용하는 $\mathrm{Q}$ 모드에서 모의 전산 실험한 결과이다. $\mathrm{Q}$ 모드에서는 향상 계층에 최대 유 효데이터인 $1152 \mathrm{kbps}$ 를 더 전송할 수 있는 모드이며, B 모 드와 마찬가지로, 기존 T-DMB의 커버리지를 유지하기 위 해서는 향상 계층에 약 $5 \mathrm{~dB}$ 의 전력이 더 필요함을 알 수 있다.

또는 $a=2$ 일 때 Rayleigh 환경에서 결과를 보면, AT$\mathrm{DMB}$ 시스템은 기존 $\mathrm{T}-\mathrm{DMB}$ 에 필요한 $\mathrm{C} / \mathrm{N} 9.6 \mathrm{~dB}$ 보다 약 $3 \sim 4 \mathrm{~dB}$ 높은 $\mathrm{C} / \mathrm{N}$ 에서 정확히, 2 배의 유효데이터를 전송할 


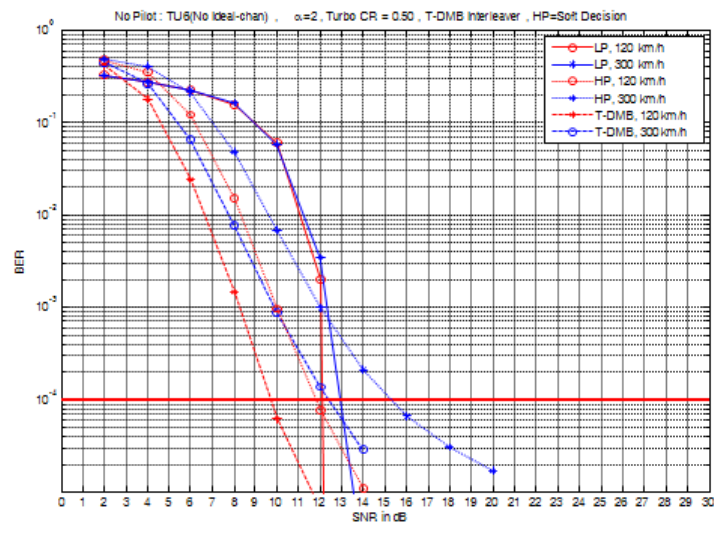

(a) 터보 부호화율:1/2, 계층변조 지수:2

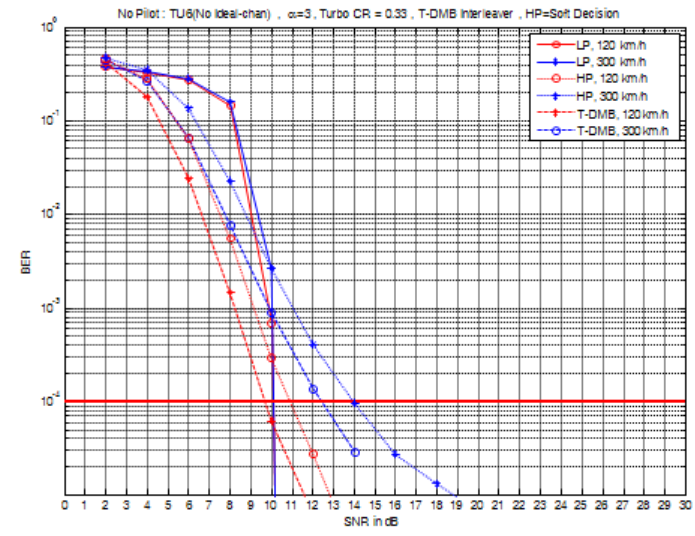

(b) 터보 부호화율:1/3, 계층변조 지수:3

그림 12. 기본계층과 향상 계층의 수신 BER 성능

Fig. 12. BER Performance of Base layer and Enhancement layer

수 있음을 알 수 있다.

그림 12 는 이동속도에 따른 기본계층과 향상 계층의 $\mathrm{BER}$ 곡선을 나타낸 것이다. 그림12의 (a)는 터보 코드의 부호율이 $1 / 2$ 이고 $a$ 가 2 일 때, (b)는 터보 코드의 부호율이 $1 / 3$ 이고 $a$ 가 3 일 때의 BER을 나타내고 있다. (a)에서 보면 BER $10^{-4}$ 이상에서는 기본계층 $(\mathrm{HP})$ 과 향상계층 $(\mathrm{LP})$ 모두 기존 T-DMB의 성능보다 떨어짐을 볼 수 있다. 이는 계층 변조에 의한 심볼간 상대적 거리가 기존 방식에 비해 줄어 듬으로 인해 발생하는 성능 열화이다. 그러나 SNR $12 \mathrm{~dB}$ 이 상, BER $10^{-4}$ 이하에서는 이동속도 $300 \mathrm{~km} / \mathrm{h}$ 의 $\mathrm{HP}$ 와 LP 의 성능이 이동속도 $300 \mathrm{~km} / \mathrm{h}$ 일 때의 T-DMB성능과 유사 하거나 우수해 짐을 알 수 있다. 이는 기존 T-DMB보다 부 호화 성능이 우수한 터보 부호화에 의해 낮은 부호화율에 서 AT-DMB 수신 성능이 우수하다는 것을 의미하며, 또한 이동속도 $300 \mathrm{~km} / \mathrm{h}$ 까지 안정적으로 지원할 수 있음을 의미 한다.

AT-DMB 방식은 이와 같이 계층변조 지수, 변조모드, 부 호화율에 따라 기존 $\mathrm{T}-\mathrm{DMB}$ 와 성능 차이의 간격이 달라짐 을 알 수 있다. 그러므로 AT-DMB 서비스의 목적이 고속 이동환경에서 안정적 서비스를 하기 위함이면 계층변조 지 수(a)를 3으로 높이고 변조모드를 B모드로 하여 계층변조 의 데이터를 고속에서 안정적으로 받을 수 있게 하고, 서비
스의 목적이 고정환경에서 고품질의 영상을 서비스하기 위 함이면 계층변조 지수를 1 로 낮추고, 변조모드를 $\mathrm{Q}$ 모드로 하여, 높은 데이터율로 전송할 수 있도록 목적에 따라 다양 하게 최적화 할 수 있다.

\section{IV. 결 론}

디지털멀티미디어 방송에서 기존 T-DMB와 호환성을 유 지하면서 고전송효율 및 고품질 서비스를 제공하기 위하여 계층변조방식을 도입한 AT-DMB 방식을 소개하였다. 이 동환경에서의 성능 향상을 위한 계층변조 $\mathrm{B}$ 모드와 고정환 경에서의 성능 향상을 위한 계층변조 $\mathrm{Q}$ 모드의 신호 생성 방식과 이에 따른 성능을 분석하였다.

분석 결과, $\mathrm{AT}-\mathrm{DMB}$ 의 계층변조 $\mathrm{B}$ 모드는 기존 $\mathrm{T}-\mathrm{DMB}$ 에 비해 유효데이터가 1.5 배 증가하고, 수신데이터 오류율 이 $\mathrm{BER}=10^{-4}$ 일때 수신 $\mathrm{SNR}$ 이 $2 \mathrm{~dB}$ 정도 더 요구되며, 계 층변조 $\mathrm{Q}$ 모드는 기존 $\mathrm{T}-\mathrm{DMB}$ 에 비해 유효데이터가 2 배 증 가하고, 수신데이터 오류율이 $\mathrm{BER}=10^{-4}$ 일 때 수신 $\mathrm{SNR}$ 이 $3 \mathrm{~dB}$ 더 요구됨을 알 수 있었다. 이 시스템을 사용하여 기존 $\mathrm{T}-\mathrm{DMB}$ 서비스와는 차별화된 새로운 서비스가 가능할 것 이라 예상된다. 


\section{참 고 문 헌}

[1] 임형택, 이상훈, 김정구, 주언경, "계층변조를 포함한 개선된 지상파 $\mathrm{DMB}$ 시스템에서 연접 부호들의 오류 성능 분석," 전자공학회논문지, 제44권, TC편, 제1호, pp.10-17, 2007년.

[2] 이광순, 임종수, 이수인, "Advanced T-DMB 기술," 한국통신학회지, 제25권, 4호, pp. 56-61, 2008년 3월 .

[3] 김짐, 강은수, 임채현, 한동석, "DQPSK 변조방삭에서의 계층변조 성능분
석," 한국방송공학회 학술발표대회 논문집, pp. 165-168, 2006년 11월.

[4] H. Jiang and Paul A. Wilford, "A Hierarchical Modulation for Upgrading digital Broadcast Systems," IEEE Trans. on broadcasting, vol. 51, no. 2, June 2005.

[5] K. F. Lee and D. B. Williams, "A space-time coded transmitter diversity technique for frequency selective fading channels," in Proc. IEEE Sensor Array and Multichannel Signal Processing Workshop, Cambridge, MA, pp. 149-152. March 2000.

저 자 소 개

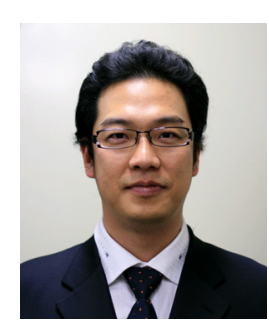

\section{이 상 진}

- 1997년 8월 : 연세대학교 전파공학과(공학사)

- 1999년 8월 : 연세대학교 전기컴퓨터공학과공학석사)

- 2005년 3월 2006년 6월 : 삼성전자 책임연구원

- 2008년 2월 : 연세대학교 전기전자공학과 박사(공학박사)

- 2008년 3월 2009년 2월 : 연세대학교 전기전자공학과 박사후연구원

- 2009년 3월 현재 : 연세대학교 전기전자공학과 연구교수

- 주관심분야 : 디지털 통신, $4 \mathrm{G}$, 휴대이동 방송, 멀티미디어 방송

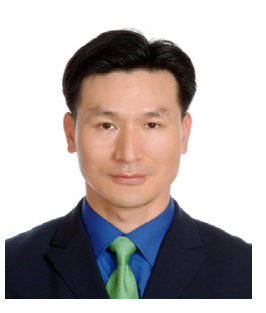

\section{이 상 운}

- 1987년 2월 : 연세대학교 전기공학과(공학사)

- 1989년 2월 : 연세대학교 전기공학과(공학석사)

- 1991년 5월 2005년 5월 : MBC 기술연구소

- 2008년 2월 : 연세대학교 전기전자공학과 박사(공학박사)

- 2005년 6월 2009년 2월 : 연세대학교 전기전자공학과 연구교수

- 2009년 3월 현재 : 남서울대학교 멀티미디어학과 교수

- 주관심분야 : 디지털 휴대이동방송, 디지털 라디오, 멀티미디어 방송, TPEG

\section{양 규 태}

- 1986년 2월 : 경북대학교 전자공학과(공학사)

- 1991년 2월 : 경북대학교 전자공학과(공학석사)

- 1991년 현재 : 한국전자통신연구원 방송시스템연구부 책임연구원

- 주관심분야 : 디지털방송시스템, DMB 시스템

\section{임 종 수}

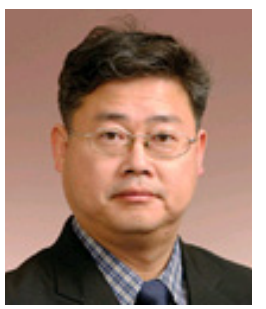

- 1988년 : 경북대학교 전자공학과(공학사)

- 1990년 : 경북대학교 정보통신공학과(공학석사)

- 1990년 1995년 : SK템레콤(주) 중앙연구소

- 1995년 1999년 : 한국통신기술(주)

- 1999년 현재 : 한국전자통신연구원 방송시스템연구부 책임연구원

- 주관심분야 : 지상파 이동방송 전송기술, 디지털 방송시스템, 영상통신 